\title{
Diagnose of the ingestion of Asclepias mellodora St. Hil. by sheep through microhistological analysis of their digestive contents ${ }^{1}$
}

\author{
María Silvia Cid ${ }^{2,3 *}$, Carolina Indurain², Ernesto Odriozola ${ }^{4}$, Miguel A. \\ Brizuela $^{2,5}$ and Marcos Lauge ${ }^{6}$
}

\begin{abstract}
Cid M.S., Indurain C., Odriozola E., Brizuela M.A. \& Lauge M. 2011. Diagnose of the ingestion of Asclepias mellodora St. Hil. by sheep through microhistological analysis of their digestive contents. Pesquisa Veterinária Brasileira 31(2):111-116. Animal Production Department, Balcarce Integrated Unit (Faculty of Agricultural Sciences, Mar del Plata National University - Balcarce Experimental Station, National Institute of Agricultural Technology), Ruta 226 Km 73.5, cc 276 (7620) Balcarce, Agentina. E-mail: scid@ balcarce.inta.gov.ar

Asclepias mellodora St. Hil. is a native acute toxic species frequent in the grasslands of the Buenos Aires province, Argentina, whose toxicity had not been assessed until now. This study evaluates the minimal lethal dose of this species for sheep, and the possibility of microscopically recognizing its fragments in gastrointestinal contents as a complementary diagnostic tool in necropsies. Three Frisona sheep (average $L W=55 \pm 4.5 \mathrm{~kg}$ ) were dosed via an esophageal tube with each one of the following doses of asclepias: 8.0, 5.0, 2.0 and 0.8 $\mathrm{g} \mathrm{DM} \cdot \mathrm{kg} \mathrm{LW}^{-1}$. Sheep poisoned with the three higher doses died between 10 and $85 \mathrm{~h}$ after intoxication, but those receiving the lower dose did not. During necropsies we: 1) determined the dry weight of the contents of rumen+reticulum, omasum+abomasum, and large intestine, 2) estimated the percentages of asclepias fragments by microanalysis correcting for digestion effects on fragment recognition, and 3) calculated the total mass of asclepias in the digestive tract of each animal. For the three higher doses, the mass of asclepias identified in the total ingesta was $12.3 \pm 3.4 \%$ of the amount supplied, possibly because of the strong diarrhea its ingestion produced. The percentages of asclepias in rumen+reticulum did not differ from the average quantified for the entire tract. The results of this study indicate that the minimal lethal doses of asclepias for sheep is between 2.0 and $0.8 \mathrm{~g} \mathrm{DM} \cdot \mathrm{kg} \mathrm{LW}^{-1}$, and that the microhistological analysis of the rumen+reticulum, the easiest region to sample, can be used to confirm the ingestion of this toxic species, although the estimated percentage will be not a good estimator of the ingested percentage.
\end{abstract}

INDEX TERMS: Poisonous plants, Asclepias mellodora, Asclepiadaceae, plant poisoning, sheep, ingestion diagnosis, microhistology.

RESUMO.- [Diagnose da ingestão de Asclepias mellodora St. Hil. por ovinos através da análise micro-histológica de seu conteúdo digestivo.] Asclepias mellodora

\footnotetext{
${ }^{1}$ Received on August 23, 2010.

Accepted for publication on September 8, 2010.

2 Facultad de Ciencias Agrarias, Universidad Nacional de Mar del Plata, Ruta $226 \mathrm{Km} \mathrm{73.5,} \mathrm{Balcarce,} \mathrm{7620,} \mathrm{Argentina.} \mathrm{*Corresponding}$ author: scid@balcarce.inta.gov.ar

${ }^{3}$ Research Fellow of Conicet, Argentina.

${ }^{4}$ EEA Balcarce INTA, Ruta 226 Km 73.5, Balcarce, 7620, Argentina.

${ }^{5}$ Comisión de Investigaciones Científicas Prov. de Buenos Aires, Argentina.

${ }^{6}$ Actividad Privada, Ruta 226 Km 73.5, Balcarce, 7620, Argentina.
}

St. Hil. é uma espécie nativa de aguda toxicidade, frequente nos campos da província de Buenos Aires, Argentina. A sua toxicidade não foi avaliada até agora. Este estudo avalia a dose mínima letal desta espécie, para os ovinos, bem como a possibilidade de reconhecer microscopicamente seus fragmentos no conteúdo gastrointestinal como uma ferramenta complementar de diagnóstico em necropsias. Três ovinos Frisona ( $P V$ média $=55 \pm 4,5 \mathrm{~kg}$ ) foram dosados através de uma sonda esofágica em cada uma das seguintes doses de Asclepias: 8,0, 5,0, 2,0 e 0,8 g DM.kg PV-1. Ovinos intoxicados com as três maiores doses morreram entre 10-85 h após a intoxicação, mas não aqueles que receberam a dose menor. Durante as necropsias se: 1) determinou 
o peso seco do conteúdo do rúmen + retículo, omaso + abomaso e intestino grosso, 2) estimou as porcentagens de fragmentos de Asclepias por microanálise, fazendo a correção para efeitos de digestão no reconhecimento dos fragmentos, e 3) calculou a massa total de Asclepias no trato digestivo de cada animal. Para as três doses maiores, a massa de Asclepias identificada na ingesta total foi de $12,3 \pm 3,4 \%$ da quantidade fornecida, possivelmente por causa da forte diarréia produzida pela sua ingestão. As porcentagens de Asclepias no rúmen + retículo não diferiram da média quantificada para o trato completo. Os resultados deste estudo indicam que a dose letal mínima de Asclepias em ovinos é de entre 2,0 e 0,8 g kg PV•DM-1, e que a análise micro-histológica do rúmen + retículo, a região mais fácil de amostrar, pode ser usada para confirmar a ingestão desta espécie tóxica, embora a percentagem estimada não será um bom estimador da porcentagem ingerida.

TERMOS DE INDEXAÇÃO: Plantas tóxicas, Asclepias mellodora, Asclepiadaceae, intoxicação por planta, ovinos, diagnosticar a ingestão, microhistologia.

\section{INTRODUCTION}

Acute toxic plant species are a major cause of economic losses to livestock production around the world (Everist 1981, Pimentel et al. 2004). In the Buenos Aires province, Argentina there is no systematic evaluation of these losses, but it is known that deaths by poisonous plant intake represent $28 \%$ of those registered by the Veterinary Diagnose Service at the Balcarce Experimental Station, National Institute of Agricultural Technology (INTA) (E. Odriozola, unpublished data). In this region, methods for detection of the toxic substances in the remains of dead animals are far beyond the analytical instrumentation availability of local diagnostic laboratories. Consequently diagnoses are made based on signs and clinical lesions. Microscopic evaluation of the ingesta for plant identification is a highly specialized technique that can be used to confirm toxic species ingestion (Yagueddú et al. 1998, Cid et al. 2003, Stegelmeier et al. 2009), representing a complement to clinical and postmortem findings. The idea of using microscopic examination of the gastrointestinal contents to diagnose plant intoxications is not new but it has not been widely utilized until now, possibly because its use requires the identification of the epidermal features of the toxic species, their resistance to digestion, and also the evaluation of the distribution of their fragments throughout the digestive tract of animals experimentally poisoned.

The acute toxic species of higher impact in the region are 'sunchillo' (Wedelia galuca (Ort.) Hoff), 'romerillo' (Baccharis coridifolia DC), and 'duraznillo negro' (Cestrum parqui L'Hérit.). For these species, it has been experimentally demonstrated that the microhistological quantification of their remains in the rumen+reticulum content of dead animals provides accurate and precise estimations of percentages in the digesta (Yagueddú et al. 1998, Cid et al. 2003). As a consequence, the microhistological analysis of the digesta of dead animals in necropsies is usually utilized in diagnosis to confirm their ingestion.
Several other species have been recognized as acute toxic by the farmers in the Buenos Aires province. Asclepias mellodora St. Hil. (asclepias), a species native from northcentral Argentina is one of them. Although the concentrations of the toxic compounds in the plants of this species are unknown, experimental intoxications have shown that a dose of $10 \mathrm{~g} \mathrm{DM} \cdot \mathrm{kg} \mathrm{LW}^{-1}$ is lethal for cattle (E. Odriozola, unpublished data). The objectives of this study were to assess the minimal lethal dose of $A$. mellodora for sheep, and the possibility of microscopically recognizing its fragments in gastrointestinal contents in necropsies, as a diagnostic tool. Whether the amount of asclepias consumed and the time between ingestion and death affects the location and mass remaining in the digestive tract in experimentally intoxicated sheep was explored. This information is necessary for the development of recommendations on how to sample the digestive track of dead animals suspected of asclepias poisoning. In addition the accuracy and precision of the microhistological estimations were evaluated, since usually farmers and veterinarians do not only want to know which toxic species has possible caused the death of the animal, but also in what percentage it was consumed.

\section{MATERIALS AND METHODS}

The study was conducted at the Balcarce Integrated Unit, Buenos Aires province, Argentina (374' $\left.\mathrm{S}, 58^{\circ} 18^{\prime} \mathrm{W}\right)$, and consisted of 2 trials.

In Trial 1 the percentage of Asclepias mellodora fragments recognizable after an in vitro digestion was evaluated.

In Trial 2, three sheep were experimentally intoxicated with each one of the following doses of asclepias: 8.0, 5.0, 2.0 and $0.8 \mathrm{~g} \mathrm{DM} \cdot \mathrm{kg} \mathrm{LW}^{-1}$ (from here Dose 8, Dose 5, Dose 2 and Dose 0.8 , respectively), and thereafter the clinical signs they presented, whether they died, and the time between intoxication and dead were registered.

During the necropsies the rumen and reticulum, omasum and abomasum and large intestine contents were gathered, their net dry weight was registered, and they were sampled for microhistological quantification of asclepias percentages. With the information obtained from both trials, the mass of the toxic specie in the ingesta for each dose was calculated, and expressed them as a percentage of the amount supplied. In this calculation, the percentage of recognizable fragments after digestion estimated in Trial 1 was used as a correction factor to account for the unrecognizable fragments of this species. Finally, for each dose it was evaluated whether the percentages and mass of asclepias in the total ingesta differed from those in rumen+reticulum, the easiest region to sample in field conditions.

\section{Trial 1 (Digestion trial)}

The microhistological technique allows for the quantification of the percentage of different species in ground vegetation samples, and in samples of sheep digesta by the identification at species level of the fragments that integrate them. This is possible because most of these fragments maintain the epidermis, the only vegetal tissue with taxonomic value that is not totally degraded by digestion. However, digestion can reduce the percentage of the identifiable fragments (Leislie et al. 1983, Samuel \& Howard 1983, Holechek \& Valdéz 1985). 
For this reason, the percentage of recognizable fragments in ground samples of asclepias after in vitro digestion was estimated. All the plants utilized in the study were collected in December 2005 in a farm located in Pila County (Buenos Aires province) where cases of intoxication had previously occurred. At the time of harvest plants were in bloom. In trial 1, six samples of 10 plants each were utilized. Five of these samples were used to estimate the percentages of recognizable fragments after in vitro digestion. The other was sorted in leaves, stems and flowers, and was used to characterize the epidermal features of the different parts of the plant of asclepias. All samples were dried for $24 \mathrm{~h}$ at $60^{\circ} \mathrm{C}$, and ground in a Wiley mill with a 1 $\mathrm{mm}$ sieve screen. Then, the whole-plant samples were in vitro digested during $24 \mathrm{~h}$ in a Daisy II Ankom Tech. incubator, using ruminal liquor from a steer fed on a lucerne hay maintenance diet. Incubation was stopped at 24 hours because the information available at this point indicated that $A$. mellodora causes death to cattle within this period (E. Odriozola, unpublished data). After 24 hours of microbial digestion, the digestion residues were recovered by filtration and were dried. Finally, whole plant digested samples and those of undigested leaves, stems and flowers were soaked in domestic bleach to remove plant pigments. Five slides were prepared for each sample. Plant part samples were used to describe the epidermal features in vegetative and reproductive structures. In digested samples, recognizable and unrecognizable fragments in 20 microscope fields per slide were registered, and results were expressed as percentages of recognizable fragments.

\section{Trial 2 (Intoxication trial)}

In December 2006, 12 Frisona ewes (average LW=55 \pm 4.5 $\mathrm{kg}$ ) were randomly assigned to each one of the doses considered in the study. Sheep were housed in separate pens, and fed with tall wheatgrass (Thinopyrum ponticum (Popd.), Bartworth \& Dewey) hay during 10 days. Water and hay were offered ad libitum. Thereafter, sheep were deprived of food during $24 \mathrm{~h}$ to generate a situation of low forage availability, similar to those natural situations in which animals usually consume toxic species (James et al. 1980, Everist 1981). Finally, sheep were dosed via esophageal tube. Experimental intoxications were done taken in account the general rules for animal welfare of the Veterinary Sciences Faculty, National University from the Central Buenos Aires, Argentina.

After intoxication animals were offered hay and water at libitum again. The plant material used in the intoxication comes from the same site than that used in trial 1. In order to calculate the amount of fresh plant material to be administered to the animals, the DM percentage of three groups of plants $\left(60^{\circ} \mathrm{C}\right.$, $24 \mathrm{~h})$ was estimated. The DM percentage was $18 \pm 0.5 \%$. Plants were dried $\left(60^{\circ} \mathrm{C}, 24 \mathrm{~h}\right)$, ground with $2 \mathrm{~mm}$ sieve, mixed in a warm water slurry and gavaged with a stomach tube. Plant material was mixed with the smallest amount of water required to provide the thickest slurry that flowed through the cannula. Animals were watched at regular intervals, and the day and hour of their death were registered. Two of the animals intoxicated with Dose 2 died during the night, and when they were found early in the morning presented a high degree of autolysis. Because animals in this condition are not necropsied for diagnosis, they were excluded from the experiment. At this time, the third animal intoxicated with the lower dose showed the signs produced by the higher doses, and it was sacrificed by electric shock. Any of the animals intoxicated with Dose 0.8 died, but they showed the signs of poisoning usually produced by non-lethal doses of this species, like diarrhea, anorexia and depression. These animals were recovered after 2 days.

Upon necropsy the entire content of the digestive of the omasum+abomasum and the large intestine of each animal were taken, dried and weighted. Because of its large size, the manipulation of the rumen+reticulum content is cumbersome, so the quantification of the botanical composition of this region was performed on a sample composed of 15 randomly taken sub-samples of $50 \mathrm{~g}$ DM each. This number of sub-samples ensures to cover the heterogeneity of fragments in rumen+ reticulum (Yagueddú et al. 1998). The remaining mass of the rumen +reticulum was also dried and weighed, to establish the total net weight of the digestive content of this region. The small intestines of the sheep intoxicated with the three higher doses were emptied. All the samples were processed as described by Yagueddú et al. (1998). Finally, fragment density of asclepias and tall wheatgrass fragments were registered in 100 microscopic fields as an estimation of their relative dry weight. The density of unidentifiable fragments was also recorded. The mass of each toxic species in the digesta of each sheep was estimated by accounting for the percentage of recognizable fragments after digestion, following the steps describe by Cid et al. (2003).

\section{Data analysis}

For the two higher doses, the DM content, and the percentage and the mass of asclepias in each region of the tract were analyzed by ANOVA, with dose and region and their interaction as sources of variation. The entire mass of the digesta and asclepias were also analyzed by ANOVA, with dose as source of variation. In addition, the average value of each one of these variables was compared by t-test with the single value from Dose 2. Furthermore, for the two higher doses, and also by ttest, the mass of asclepias in rumen+reticulum was compared with the amount supplied to evaluate whether the percentage and the mass of asclepias in the rumen+reticulum differed from those in the total digesta. All these tests were performed on the percentages corrected for digestion. All the mentioned differences are significant at $\alpha=0.05$, unless otherwise is stated.

\section{RESULTS}

\section{Trial 1}

The epidermis of Asclepias mellodora has features with taxonomic value, which allows the identification of its fragments in mixes with the species in the Flooding Pampa, where intoxication with this species may occur (Fig.1). All the features observed in the $A$. mellodora epidermis are in agreement with those described for the genus Asclepias by Metcalfe \& Chalk (1950). The percentage of recognizable fragments in whole plant samples after digestion was $30.0 \pm 3.7 \%$.

\section{Trial 2}

The time lapsed between the intoxication of a given animal and its death, as well as the signs animals presented after intoxication differed among doses. The animals receiving Dose 8 died between 10 to $18 \mathrm{~h}$; those receiving Dose 5 between 13 to $35 \mathrm{~h}$; and the ones receiving Dose 2 between 46 to $85 \mathrm{~h}$. Animals receiving Dose 8 had the abdomen enlarged, showed signs of anorexia, and had strong diarrea. 

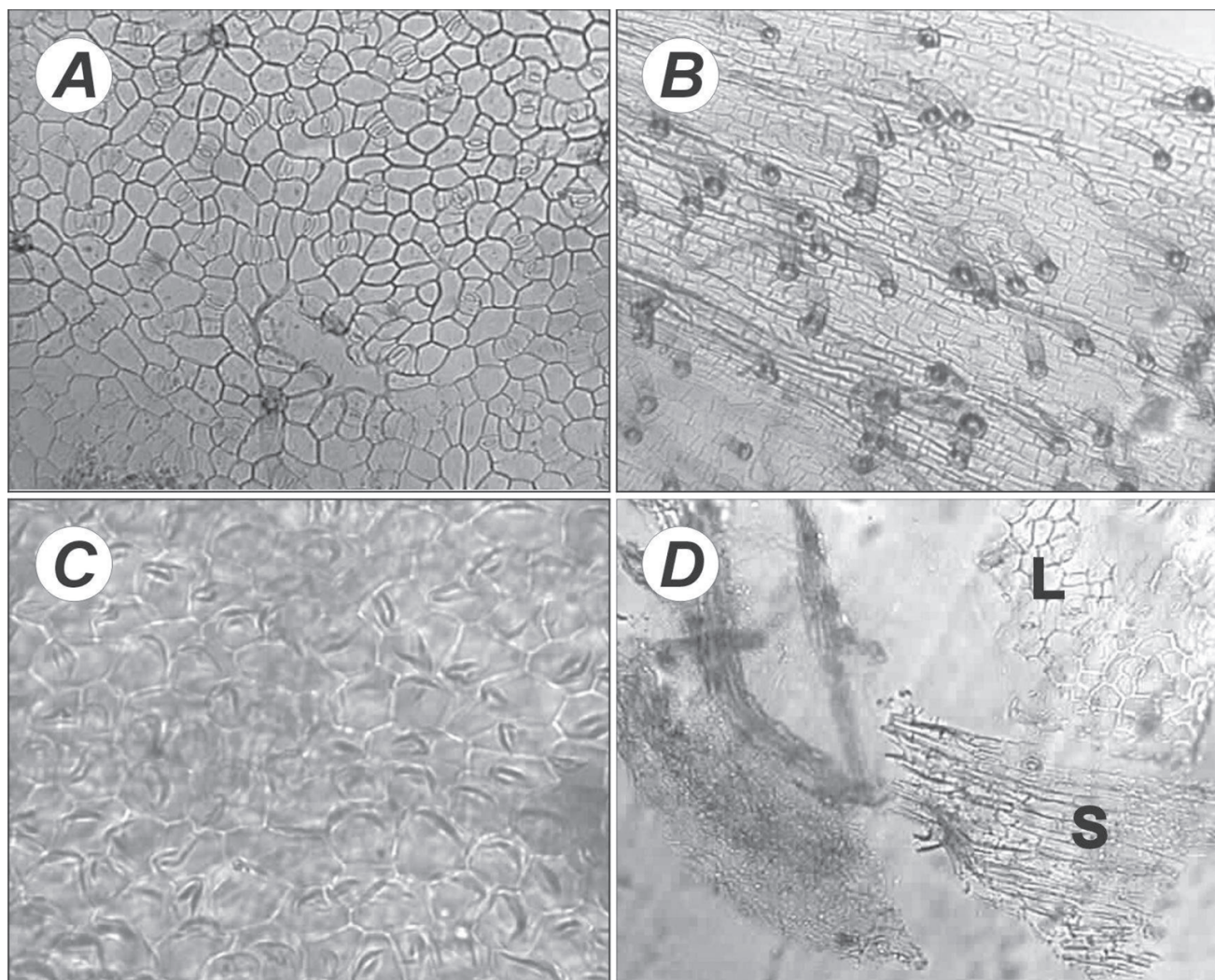

Fig.1. Epidermal features of Asclepias mellodora in leaves (A), stems (B) and flowers (C), and in fragments of plants at reproductive stage after digestion (D). $L=$ leaf fragment, $S=$ stem fragment.

Those receiving Dose 5 had the same sings but were also prostrated and weak, breathed with difficulty, and slavered in abundance. Animals intoxicated with Dose 2 showed all the mentioned signs, but they appeared at longer times. The lesions presented by the animals in this experiment were described in detail elsewhere (Lauge \& Odriozola, 2008).

The total content of the digestive tract did not differ between the animal intoxicated with the two higher doses $(120.9 \pm 38.2 \mathrm{~g} \mathrm{DM})$, but it did differ among regions. In animals that received Doses 8 and 5 the omasum+abomasum and the large intestine contents were 13.1 and $5.1 \%$ of that of the rumen+reticulum, respectively. The variability among animals of the total digestive content was higher for Dose 5 than for Dose 8 (variation coefficients were 40 and 23, respectively). The content of the entire digestive tract of the animal intoxicated with Dose 2 that did not suffer autolysis was $30 \%$ lower than that of those intoxicated with higher doses. The content in rumen+reticulum represented $81.9 \%, 87.8 \%$ or $70.0 \%$ of total in sheep dosed Dose 8 , Dose 5 and Dose 2, respectively (Table 1).

Fragments of $A$. mellodora were found in the three regions of the digestive tract of all the animals, regardless of the dose. The percentage of these fragments corrected by digestion was higher in the animals intoxicated with Dose 8 than in those receiving the intermediate dose. In both groups this percentage remained constant throughout the regions (Dose $8=45.7 \pm 5.7 \%$, Dose $5=32.8 \pm 0.6 \%$ ). The percentage of asclepias in the digesta of the animal receiving Dose 2 strongly decreased in the two last regions of the tract, and the percentage calculated for the entire digestive content $(11.4 \%$ ) was less than half of the average of those intoxicated with D5 (Table 1).

The mass of asclepias calculated for the different regions of the tract of animals receiving Doses 8 and 5, differed according the dose (dose $x$ region interaction, $p=0.07$ ). In the rumen+reticulum the mass of asclepias was $42 \%$ lower in the animals receiving Dose 5 than in those receiving Dose 8; in the other two regions it was similar between doses (Table 1). This pattern also applies to the necropsed sheep intoxicated with Dose 2, in which the mass of asclepias in the rumen+reticulum was a third than that in the ones of the intermediate dose. In summary, for the three doses, the mass of asclepias was higher in rumen+reticulum than in the other regions, and this difference decreases as the dose decreases.

The percentage of $A$. mellodora mass dosed to the sheep represented by that estimated in the total digesta did not differed between Dose 8 and Dose 5, averaging $12.3 \pm 3.4 \%$. It was $10.2 \%$ for the sheep intoxicated with Dose 2 . In addition, neither the percentage nor the mass of asclepias in the rumen+reticulum of sheep dosed with Doses 8 and 5 differed from those in the total digesta. For the sheep intoxicated with Dose 2, the percentage of asclepias in rumen+reticulum was $14.1 \%$, and that in total digesta was $11.4 \%$; the masses were 8.3 and $9.6 \mathrm{~g}$, respectively (Table 1 ). 
Table 1. Average $(X \pm S D)$ net dry weight of the ingesta of sheep experimentally poisoned with three doses of Asclepias mellodora, the percentage of this species quantified by microanalysis, its calculated mass, and the percentage of the amount supplied represented by the amount estimated by microanalysis

\begin{tabular}{|c|c|c|c|c|c|c|}
\hline \multirow{2}{*}{ Doses } & \multicolumn{3}{|c|}{ Ingesta } & \multirow[t]{2}{*}{ Total } & \multirow{2}{*}{$\begin{array}{l}\text { Mass of the } \\
\text { toxic species } \\
\text { supplied (g) }\end{array}$} & \multirow{2}{*}{$\begin{array}{c}\text { Mass } \\
\text { recovered } \\
(\%)\end{array}$} \\
\hline & $\begin{array}{l}\text { Rumen+ } \\
\text { Reticulum }\end{array}$ & $\begin{array}{l}\text { Omasum+ } \\
\text { Abomasum }\end{array}$ & $\begin{array}{c}\text { Large } \\
\text { Intestine }\end{array}$ & & & \\
\hline \multicolumn{7}{|l|}{$8 \mathrm{~g} \mathrm{DM} \cdot \mathrm{kg} \mathrm{LW}{ }^{-1}$} \\
\hline Net dry Weight (g) & $112.3 \pm 36.9 a$ & $15.9 \pm 4.3 b$ & $8.8 \pm 7 b$ & $136.9 \pm 32.4 \mathrm{~A}$ & & \\
\hline $\begin{array}{l}\% \text { asclepias (corrected } \\
\text { by digestion) }\end{array}$ & & $47.2 \pm 7.9 a$ & $43.9 \pm 5.6 a$ & $40.4 \pm 8.1 \mathrm{a}$ & $45.7 \pm 5.7 \mathrm{~A}$ & \\
\hline Asclepias mass $(\mathrm{g})$ & $51.4 \pm 13.2 a$ & $6.8 \pm 1.1 b$ & $3.7 \pm 3,2 b$ & $61.9 \pm 13.7 A$ & $437.0 \pm 12.2$ & $14.2 \pm 3.2 \mathrm{~A}$ \\
\hline \multicolumn{7}{|l|}{$5 \mathrm{~g} \mathrm{DM} \cdot \mathrm{kg} \mathrm{LW}^{-1}$} \\
\hline Net dry Weight $(\mathrm{g})$ & $91.8 \pm 36.2 \mathrm{a}$ & $16.1 \pm 1.1 b$ & $2.3 \pm 1.8 \mathrm{~b}$ & $104.8 \pm 42.6 \mathrm{~A}$ & & \\
\hline $\begin{array}{l}\% \text { asclepias (corrected } \\
\text { by digestion) }\end{array}$ & & $33.1 \pm 1.1 b$ & $33.9 \pm 1.3 b$ & $15.5 \pm 9.4 b$ & $32.8 \pm 0.6 \mathrm{~B}$ & \\
\hline Asclepias mass (g) & $30.2 \pm 11.3 a$ & $5.5 \pm 3.2 b$ & $0.4 \pm 0.4 b$ & $36 \pm 13.5 B$ & $281.6 \pm 20.8$ & $12 \pm 4.1 \mathrm{~A}$ \\
\hline \multicolumn{7}{|l|}{$2 \mathrm{~g} \mathrm{DM} \cdot \mathrm{kg} \mathrm{LW}{ }^{-1}$} \\
\hline Net dry Weight (g) & 58.7 & 16.5 & 8.6 & 83.8 & & \\
\hline $\begin{array}{l}\% \text { asclepias (corrected } \\
\text { by digestion) }\end{array}$ & 14.1 & 6.6 & 2.6 & 11.4 & & \\
\hline Asclepias mass $(\mathrm{g})$ & 8.3 & 1.1 & 0.2 & 9.6 & 94.0 & 10.2 \\
\hline
\end{tabular}

Averages followed by different capital letter differ among doses, and followed by different lower letter differ among regions $(p<0.05)$. Mass recovered $(\%)=(\text { total mass of asclepias in the digestive tract } / \text { mass supplied })^{*} 100$.

\section{DISCUSSION}

The fragments of Asclepias mellodora have epidermal features of taxonomic value. However, the percentage of recognizable fragments after digestion in this species is low (30\%), and lower than that determined for other acute toxic species that also grow in the Buenos Aires province, such as duraznillo negro (73\%) and sunchillo (51\%) (Cid et al. 2003), although the three of them had similar DM percentage (from 18\% to $20 \%$ ). The epidermis is covered by indigestible cutine that inhibits digestion, protecting cell walls of microbe attacks. Cutinization increases with the stage of growth (Wilson et al. 1976), thus, it is possible that the percentage of recognizable fragments of asclepias be even lower in plants at vegetative stage.

Asclepias plants were toxic for sheep at doses ranging from 0.8 to $8.0 \mathrm{~g} \mathrm{DM} \cdot \mathrm{kg} \mathrm{LW}^{-1}$, and the time lapsed between intoxication and death differed according to the dose, increasing more than proportionally as the dose decreased. The lower the dose, and closer to the minimal lethal one, the higher the variability in time of death among animals. The signs observed in the animals agree with those described for other species of the genus Asclepias (Kingsbury 1964, Seiber et al. 1984).

The mass of the digestive content and its distribution through the digestive tract were similar in animals intoxicated with the Doses 8 and 5, although the variability among animals in total content was higher for Dose 5 . The estimated percentage of $A$. mellodora was higher at Dose 8 than at Dose 5. When the dose was $2 \mathrm{~g} \mathrm{DM} \cdot \mathrm{kg} \mathrm{LW}^{-1}$ the amount of asclepias retained in the digestive tract was the lowest. Nevertheless, the percentages of the mass supplied by asclepias found in the digesta were similar among doses, ranging from 10 to $14 \%$. These percentages are lower than those found in other experiments of forced intoxication done with other acute toxic species. Cid et al. (2003) reported recovers of $96.5,92.2$ and $92.0 \%$ of the amount supplied for duraznillo negro, romerillo and sunchillo, respectively. A low recovery of a toxic species fragments in the digesta of a dead animal could be related to their high degradation by digestion, or to their lost in the feces produced from intake to dead. In this study, fragment quantification was corrected by digestion effect, but because their liquid consistence, feces were not gathered. Consequently, it is assumed that the last was the cause of the low mass of asclepias recovered at all the doses. In their study, Cid et al. (2003) gathered the feces produced by the animals between intoxication and death, analyzing the mass of the toxic species in them. They found that the mass of toxic species in feces was high only for duraznillo negro, representing $15 \%$, acute toxic species that does not produce diarrhea (López et al. 1991). In spite of the losses by diarrhea, for Doses 8 and 5, the percentage and the mass of $A$. mellodora estimated for the entire digestive tract did not differ from those estimated in rumen+reticulum, which means that sampling this region is appropriate for diagnosing its intake. For the Dose 2, the values for these two variables were similar in absolute value.

Although the presence of the remains of a toxic species in the gut provides a definitive evidence of its consumption, it does not prove that this plant species caused the poisoning. However, microscopic findings, along with clinical disease and postmortem findings help to achieve the most likely diagnosis. Our results indicate that to determine whether animals, which died in grazing conditions, had consumed asclepias, it would be enough to sample the content of rumen+reticulum, the easiest region of the tract to reach. Findings also show that, if the stage of decomposition of the 
animal allows to sample the digestive tract, asclepias fragments can be recognized even when death had occur 5 days after ingestion. Moreover, the analysis of the digestive contents for poisonous plant fragments identification might be one of the few diagnosis tests available for animals that are in poor postmortem condition.

Results showed three patterns in the variability in signs and digesta contents that should be considered when collecting samples to make diagnostics. These patterns are: 1) The increase in the variability of the signs in sheep as doses decreased, 2) the variability found in the total content of the tract, and 3) the variability in the mass of asclepias in the total digesta for the two higher doses. These patterns indicate that, cases in which several animals died, it would be convenient to sample the rumen+reticulum from more than one animal for diagnosis purposes.

Our findings show that, at the reproductive stage of growth, plants of Asclepias mellodora growing in the southern of the Buenos Aires province, Argentina, are toxic to sheep at doses higher than $0.8 \mathrm{~g} \mathrm{DM} \cdot \mathrm{kg} \mathrm{LW}^{-1}$. They also show that the microhistological analysis of gastrointestinal contents can be used as a complementary diagnostic tool in cases of suspected poisoning with this species. Samples form the rumen+reticulum of animals found dead in the field, would allow to confirm asclepias ingestion, but will not provide a good estimation of the amount in which it was ingested, as for other acute toxic species.

Acknowledgements.- The research was funded by the Agencia Nacional de Promoción Científica y Tecnológica de Argentina (Grant 0208-11339), and the UNMdP, Argentina.

\section{REFERENCES}

Cid M.S., López T.A., Yagueddú C. \& Brizuela M.A. 2003. Acute toxic plant estimation in grazing sheep ingesta and feces. J. Range Manage. 56:353-357.
Everist S.L. 1981. Poisonous Plants of Australia. $2^{\text {nd }}$ ed. Angus and Robertson Publishers, Sydney, Australia. 966p.

Holechek J.L. \& Valdéz R. 1985. Evaluation of in vitro digestion for improving botanical estimates of mule deer fecal samples. J. Mamm. 66:574-577.

James L.F., Keeler R.F. \& Johnson A.E. 1980. Plants poisonous to livestock in the Western states USDA ARS Agric. Inform. Bull., Washington DC. 415p.

Kingsbury J.M. 1964. Poisonous Plants of the United States and Canada. Prentice-Hall, Englewood Cliffs, New Jersey. 589p.

Lauge M.V. \& Odriozola E. 2008. Intoxicación experimental de ovinos con Asclepias mellodora St. Hilaire (yerba de la víbora). Veterinaria Argentina 25(241):22-31.

Leislie D.M., Martin J.R., Starkey E.E. \& Slater R.C. 1983. Correcting for differential digestibility in microhistological analysis involving common coastal plants of the Pacific Northwest. J. Range Manage. 36:730-732.

López T., Odriozola E. \& Eyherabide J. 1991. Toxicidad Vegetal para el Ganado: patología, prevención y control. Centro Regional Buenos Aires Sur, Instituto Nacional de Tecnología Agropecuaria, Balcarce, Buenos Aires, Argentina. 56p.

Metcalfe C. \& Chalk L. 1950. Anatomy of the Dicotyledons, p.7251500. Vol.2. Oxford University Press, London.

Pimentel D., Zuniga R. \& Morrison D. 2004. Update of the environmental and economic costs associated with alien-invasive species in the United State. Ecol. Econ. 52:273-288.

Samuel M.J. \& Howard G.S. 1983. Disappearing forbs in microhistological analysis of diets. J. Range Manage. 36:132-133.

Stegelmeier B.L., Green B.T., Panter K.E., Welch K.D. \& Hall J.O. 2009. Identifying plant poisoning in livestock. Rangelands 31:5-9.

Seiber J.N., Lee S.M. \& McChesney M.M. 1984. New cardiac glycosides (cardenolides) from Asclepias species, p.427-437. In: Seawright A.A. et al. (Eds), Plant Toxicology. Proceedings of Australia-U.S.A. Poisonous Plants Symposium, Brisbane, Australia.

Wilson J.R. 1976. Variation in leaf characteristics with level of insertion on a grass tiller. II. Anatomy. Aust. J. Agric. Res. 27:343-364.

Yagueddú C., Cid M.S. \& López T.A. 1998. Microhistological analysis of sheep gastrointestinal content to confirm poisonous plant ingestion. J. Range Manage. 51:655-660. 